\title{
Physicochemical study of Rubus fruticosus of the Mediterranean region of Morocco
}

\author{
Hafssa El Cadi ${ }^{1, *}$, Asmae El Cadi ${ }^{2}$, Btissam Ramdan ${ }^{3}$ and Jamal Brigui ${ }^{1}$ \\ ${ }^{1}$ Department of Chemistry, Laboratory of Chemical engineering and Valorization of Resources, Abdelmalek \\ Essaâdi University, Tangier, Morocco \\ ${ }^{2}$ Department of Chemistry, Laboratory of Physicochemistry of Materials, Natural Substances and Environment, \\ Abdelmalek Essaâdi University, Tangier, Morocco \\ ${ }^{3}$ Department of Biology, Laboratory of Biotechnology and Valorization of Natural Resources, Faculty of \\ Science, University Ibn Zohr - Agadir, Morocco
}

\begin{abstract}
Blackberry (Rubus fruticosus) belongs to the Rosaceae family. It is very rich in essential and beneficial elements. In Morocco, despite its nutritional quality, this fruit remains among the forest species that are ignored. The present study has been focused on the physicochemical characterization of this species. The fruits have been harvested from the Mediterranean region of Morocco (Tangier-Tetouan-Al Hoceima). The analysis was made directly after the harvest for the determination of $\mathrm{pH}$ value, acidity, Total soluble solid, refraction index, total and reducer sugar levels. Results showed that the fruit is acidic $(\mathrm{pH} 4.65 \pm 0.32)$, rich in water $(70 \%)$ and total sugars $(27.43 \pm 2.67 \mathrm{mg} / \mathrm{l})$. The variation of different physicochemical parameters in all fruit samples collected from different sites may be due to geographical distribution, climatic and edaphic parameters.
\end{abstract}

Keywords: Blackberry; Forest species; Physicochemical analysis; climatic.

\section{Introduction}

Currently, in food, people are looking for plants or their fruits with good nutritional quality and which are beneficial to human health. One of the fruits which we want to enhance in Morocco is the wild bramble (Rubus fruticosus) that exists in the Mediterranean forests. Blackberry above all is characterized by the presence of a more or less dense coat of spines on its branches. The spines play two leading roles: the protection and conquest of space. The foot produces shoots. The flowers of the Bramble have five petals, five sepals and many stamens ${ }^{1}$.

Fruiting happens in the summer, usually on the twigs of two years. The fruits, fleshy, composed, formed of the agglomeration of small drupes, are edible. Rubus fruticosus is located between the 30th and 65th parallels of the northern hemisphere and between the 28th and 40th parallels of the southern hemisphere. Its range extends across Europe, North Africa (Atlas), Southern Africa, South-East Australia, New Zealand, the United States and Chile. This fruit also exists nearer to Ecuador but at higher altitudes (up to more than $2000 \mathrm{~m}$ altitude) ${ }^{1}$. However, they are mainly widespread in temperate and warm temperate

*Corresponding author: Hafssa El Cadi

Email address: hafssa.elcadi@yahoo.fr

DOI: http://dx.doi.org/10.13171/mjc10102001311086hec zones ${ }^{2}$. Common throughout Europe, it has become naturalized everywhere. It grows mainly in hedges and forests ${ }^{3}$.

As for their geographical distribution, fruits of Rubus genus are found in fertile areas, both on continents and oceanic islands. The fertilization practices can affect $\mathrm{pH}$, total soluble solids (TSS) and titratable acidity ${ }^{4,5}$. The fruit weight, TSS, $\mathrm{pH}$ and acidity of wild blackberries in Turkey were between $1.5-2.1 \mathrm{~g}$, $11.3-13.1 \%, 3.33-3.35$ and $0.7-1.0 \%$, respectively ${ }^{6}$. The same parameters of blackberry cultivars grown in a different region of Turkey were previously reported between 2.0-6.6 g, 8.98-20.2 \%, 3.3-3.6, and $1.0-3.1 \%$, respectively ${ }^{7,8,9}$.

Differences gauged between cultivars may be explained by genotype ${ }^{10,11}$, growing temperature ${ }^{12}$, growing season, maturity at harvest, environmental stress, and other factors ${ }^{13}$.

A well-known plant, growing in abundance on wet slopes, along paths, in hedges, bushes, on the edge of forests, in woods where it spreads rapidly. Not to be confused with mulberry, whose fruit is also called blackberry although these fruits are very similar, both in appearance and taste. The data on the

Received September 25, 2019

Accepted November 15, 2019

Published January 31, 2020 
composition of this species in the studies regions, including the information of physicochemical characteristics have not yet been explored.

The knowledge of nutritional quality is started by general physicochemical measures such as measuring $\mathrm{pH}$, dry matter and sugar content. Accordingly, this study aims to characterize this specie by physicochemical parameters and compare between these three regions.

\section{Experimental}

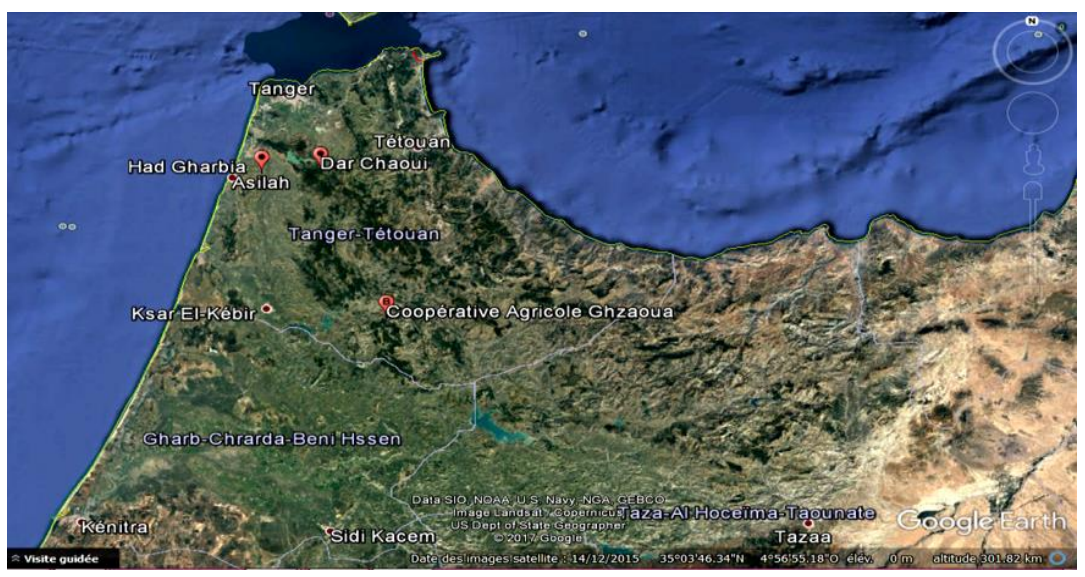

\subsection{Plant material}

Wild bramble fruit (Rubus fruticosus) were harvested in Tangier-Tetouan-Al Hoceima area, which covers $17,262 \mathrm{~km}^{2}$, located in the extreme north-west of Morocco ${ }^{14}$ (Fig. 1). The fruits were harvested at their physiological maturity in the morning and transported in boxes that were well closed and stored at Materials and Resources Valorisation Laboratory, Faculty of Sciences and Technology-Tangier. Our study is focused on three harvests of Rubus fruticosus $L$. species. The fruits were collected for 4 months (May-June-July and August 2016).

Figure 1. Geographical location of the harvest region ${ }^{15}$

\subsection{Physicochemical analyses}

The AOAC international standard methods ${ }^{16}$ were used to determine the physicochemical characteristics. Ashes and dry matter (DM) content. The $\mathrm{pH}$ measurement was made using a digital $\mathrm{pH}$ meter. Titratable acidity (TAc) was measured by the titrimetric method. The refractive index (RI) and the total soluble solid contents (was expressed as \% TSS) were determined by a digital refractometer.

\subsection{Dosage of total and reducing sugars}

Reducing and total sugars obtained after hydrolysis were determined by the Luft-Schoorl method and the number of sugars converted using the Luft-Schoorl chart ${ }^{17}$.

\subsection{Statistical analyses}

Fruit characteristics data were analyzed using analysis of variance (ANOVA).

\section{Results and Discussion}

Physicochemical parameters of fruits give a general approach to their qualitative character. Table 1 showed the higher value of $\mathrm{pH}$, RI and ash were obtained in the fruits of $\mathrm{HG}$ region. Thus, the highest value of total acidity was founded in GH samples followed by $\mathrm{HG}$ fruits. The fruits of $\mathrm{BM}$ region presented the higher percentage of TSS and ash; on the other hand, this sample presented the lowest value of titrable acidity, RI and ash. Statistically significant differences were recovered between the results of samples from the three regions for all the parameters tested $(\mathrm{p}<0.05)$. Results of $\mathrm{pH}$, titrable acidity (TAc) and total soluble solids (TSS) exhibited the average values of $4.65 \pm 0.32 ; 3.25 \pm 0.41$ and $9.8 \pm 0.76 \%$ respectively. Our results of TSS and titrable acidity were almost close to the values founded by other results $(8.34 \%$ and 2.95 , respectively) ${ }^{18}$.

Whereas, some scientific founded $\mathrm{pH}$ values from 3.33 to 4.1 and TSS was $16.2 \pm 2.7^{19}$. Moreover, the average $\mathrm{pH}$ and titratable acidity values found in the fruits of the three studied populations ranged from 3.06 to 3.11 and 2.99 to 3.28 , respectively ${ }^{20}$. Values obtained for the three populations studied were higher than those reported by Hirsch et al. (2012) for blackberry (Rubus spp.) cultivars spread in Brazil's southern region (1.30 to 1.58$)^{21}$. The average value of RI and DM results were $1.34 \pm 0.005$ and $30.29 \pm 2.68 \%$, respectively. According to other research, DM levels of $R$. fruticosus showed a percentage of $36.4 \%{ }^{22}$. Though the wet mass presented about $70 \%$ of the total mass of the fruit, these results were $10 \%$ lower than those founded by another research $(87.7 \%)^{23}$.

In general, the water content can be influenced by the age of the plant, the vegetative cycle period and even genetic factors ${ }^{23-25}$. This variation can be due also to the different pedoclimatic conditions and geographical distribution ${ }^{26}$. The percentage of TSS represents the soluble solid which shows the sugar level in fruits. The balance between TSS and titratable acidity was determined by sugars and organic acids ratio, and this determines the flavor of 
the fruit. This balance obtained was between $1.55 \pm 0.38$ and $2.3 \pm 0.38$. The average value of this ratio which was obtained by other publications was $3.06 \% 18$. The mineral matter value obtained was $4.46 \pm 2 \%$. However, ash content must have a threshold not to exceed for human and animal consumption. It also varies according to geographic origin ${ }^{27}$. Fruit parameters like titratable acidity, $\mathrm{pH}$ and TSS contents depend upon the stage of fruits collection and the area climatic and geological condition from where fruits were collected 19-28. Determination of these parameters is of primary interest and first step during the qualitative evaluation of fruits, and it dictates further studies on components which seem more attractive.

Table1. Physicochemical parameter characteristics of Rubus fruticosus.

\begin{tabular}{|l|c|c|c|c|c|c|c|}
\hline $\begin{array}{c}\text { Harvesting } \\
\text { site }\end{array}$ & pH & $\begin{array}{c}\text { Acidity } \\
(\mathbf{A})\end{array}$ & $\begin{array}{c}\text { TSS } \\
\mathbf{\%}\end{array}$ & TSS/A & RI & $\begin{array}{c}\text { DM } \\
\text { \% }\end{array}$ & $\begin{array}{c}\text { Ash } \\
\text { \% }\end{array}$ \\
\hline BM & $4.75 \pm 0.32$ & $4.55 \pm 0.66$ & $10.5 \pm 0.76$ & $2.3 \pm 0.38$ & $1.338 \pm 0.005$ & $32.24 \pm 2.68$ & $2.5 \pm 2.17$ \\
\hline GH & $4.3 \pm 0.32$ & $5.8 \pm 0.66$ & $9 \pm 0.76$ & $1.55 \pm 0.38$ & $1.347 \pm 0.005$ & $27.23 \pm 2.68$ & $4.1 \pm 2.17$ \\
\hline HG & $4.92 \pm 0.32$ & $4.8 \pm 0.66$ & $10 \pm 0.76$ & $2.08 \pm 0.38$ & $1.349 \pm 0.005$ & $31.41 \pm 2.68$ & $6.8 \pm 2.17$ \\
\hline Mean & $4.65 \pm 0.32$ & $5.05 \pm 0.66$ & $9.8 \pm 0.76$ & $1.82 \pm 0.38$ & $1.34 \pm 0.005$ & $30.29 \pm 2.68$ & $4.46 \pm 2.17$ \\
\hline
\end{tabular}

BM: Beni messaouar/ GH: ghezaoua/ HG: Had Gharbia

RI: Refractive Index / DM: Dry Matter / TSS: total soluble solids/ TAc: titrable acidity

Sugars are the most important constituents of $R$. fructicocus fruit. They are also responsible of the food sweetness ${ }^{27}$. Results showed an average value of $27.43 \pm 2.67 \mathrm{mg} / \mathrm{l}$ of the total sugars and $22.4 \pm 2.6$ $\mathrm{mg} / \mathrm{l}$ of the reducing sugars. The fruits of GH region presented the higher content of reducing and total sugars followed by BM fruits and HG fruits were the last. The variations in sugar content can be attributed to several factors such as the age of the plant, the load of burn, the maturation stage and the physiological state of the fruit during the analysis.

Others factors such as exposure duration to the sun, climate and availability of water can also affect sugar contents ${ }^{28-33}$. Therefore, these fruits would constitute a significant source of sugars that provides calories and give fruits their pleasant flavors. Indeed, a high concentration of sugars prevents bacterial proliferation in jams and jellies what contributes to the processing of these fruits into several food products, especially jams, compotes, marmalades and juice ${ }^{34}$. According to Sakamura and Suga ${ }^{35}$ the majority of fruit sugars are represented mainly by glucose and fructose. According to Ayaz et al ${ }^{36}$, the variation of reducing sugar can be attributed to different factors including the ripening stage, the temperature, the duration of exposure to the sun, and weather condition.

Table 2. Total and reducing sugars in Rubus fruticosus.

\begin{tabular}{|l|c|c|}
\hline Harvesting site & Reducing sugars (mg/l) & Total sugars \\
\hline BM & $22.4 \pm 2.6$ & $27 \pm 2.67$ \\
\hline GH & $25 \pm 2.6$ & $30.3 \pm 2.67$ \\
\hline HG & $19.8 \pm 2.6$ & $25 \pm 2.67$ \\
\hline Mean & $22.4 \pm 2.6$ & $27.43 \pm 2.67$ \\
\hline
\end{tabular}

BM: Beni messaouar/ GH: ghezaoua/ HG: Had Gharbia

The obtained results showed that the fruit is acidic in nature, rich in water and total sugars which were represented by reducing and non-reducing sugars.

\section{Conclusion}

Results of our study showed water content of $70 \%$ and a rate of ashes of $4.46 \pm 2.17 \%$. Our fruit was acidic and had a $\mathrm{pH}$ value of $4.65 \pm 0.32$, titratable acidity of $5.05 \pm 0.66$ and TSS of $9.8 \pm 0.76 \%$. Also, values for reducing and total sugars were $22.4 \pm 2.6$ $\mathrm{mg} / \mathrm{l}$ and $27.43 \pm 2.67 \mathrm{mg} / \mathrm{l}$, respectively. This study implies that wild-growing blackberries present an average variation on Physicochemical characteristics. This wild blackberry needs more study in identification and quantification of the bioactive constituents of fruit, seeds, flesh and peel. Also, their influence on human health needs to be discovered. As it has high acidity, it is an important mineral source when compared to the same genus cultivars. Thus, this study contributes to the improvement of scientific knowledge on the native plants of the region.

\section{Acknowledgement}

We are grateful to the laboratory of Biochemistry and Molecular Genetics for their help in the analysis carried out. We also thank the property owners who 
provided access to their properties for species sampling.

\section{Conflict of Interest}

Authors declare no conflict of interest.

\section{References}

1- L. Wehrle, La ronce (Rubus fruticosus L. agg.) in forest, Revue Forestière Française, 1985, 288-304.

2- S. Baret, S. Maurice, T. Le Bourgeois, D. Strasberg, Altitudinal variation in fertility and vegetative growth in the invasive plant Rubus alceifolius Poiret (Rosaceae), on Réunion island. Plant Ecology, 2004, 172, 265-273.

3- A. C. H. Thanina, M. Bendahou, K. Arab. Antibacterial activity of two extracts from Rubus fruticosus $L$. against resistant pathogens and their antioxidant potential. African Journal of Microbiology Research, 2015, 9(18), 1255-1262.

4- R. E. Smart, Canopy microclimate implications for nitrogen effects on yield and quality International Symposium on Nitrogen in Grapes and Wine, American Society for Enology and Viticulture, 1991, 90-101.

5- K. L. Chadha Close, S. D. Shikhamany, The Grape Improvement, Production and Post-harvest Management Malhotra Publishing House, New Delhi, 1999.

6- K. U. Yilmaz, Y. Zengin, S. Ercisli, S. Serce, K. Gunduz, M. Sengul, B. M. Asma, Some selected physic-chemical characteristics of wild and cultivated blackberry fruits (Rubus fruticosus L.) from Turkey, Biotechnol. Lett., 2009, 14(1), 4152-4163.

7- Y. S. Agaoglu, S. P. Eyduran, E. Eyduran, Comparison of some pomological characteristics of blackberry cultivars growth in Ayas conditions, Journal of Agricultural Sciences, 2007, 13(1), 69-74.

8- L. R. Clark, J. R. Howard, C. Brownmiller, Antioxidant capacity and phenolic content in blueberries as affected by genotype and growing season. Journal of the Science of Food and Agriculture, 2003, 83, 1238-1247.

9- M. Minoggio, L. Bramati, P. Simonetti, C. Gardana, L. Lemoli, E. Santangelo, P. L. Mauri, P. Spigno, G. P. Soressi, P. G. Pietta, Polyphenol pattern and antioxidant activity of different tomato lines and cultivars, Ann Nutr Metab., 2002, 47, 64-69.

10-G. O. Perez-Tello, B. A. Silva-Espinoza, I. Vargas-Arispuro, B. O. Briceno-Torres, M. A. Martinez- Tellez, Effect of temperature on enzymatic and physiological factors related to chilling injury in carambola fruit (Averrhoa carambola L.), Biochemical and Biophysical Research Communication, 2001, 287, 846-851.

11-A. Kirakosyan, P. Kauffman, S. Warber, S. Zick, K. Aaronson, S. Bolling, S. C. Chanc, Applied environmental stresses to enhance the levels of polyphenolics in leaves of hawthorn plants, Physiol Plantarum., 2004, 121, 182-186.

12-High Commission for Planning of Morocco; 2018, http://rgphencartes.hcp.ma/.

13-Google Earth; https://earth.google.com/.

14-G. E. Latimer, W. Horwitz, Official methods of analysis. Association of Official Analytical Chemists (AOAC) International, (19 th ed.) Canada: $A O A C, \mathbf{2 0 1 2 .}$

15-G. Marrubini, A. Papetti, E.Genorini, A. Ulrici, Determination of the Sugar Content in Commercial Plant Milks by Near Infrared Spectroscopy and Luff-Schoorl Total Glucose Titration. Food Analytical Methods, 2017, 10(5), 1556-1567.

16-M. Zia-Ul-Haq, M. Riaz, V. DeFeo, H. Z. E. Jaafar, M. Marius, Rubus fruticosus L.: constituents, biological activities and health related uses, Molecules, 2014, 19(8), 1099811029.

17-M. Teixeiraa, T. Altmayera, F. Bruxela, C. R. Orlandia, N. F. de Mourab, C. N. Afonsoc, E. M. Ethura, D. L. Hoehnea, E. M. de Freitas, Rubus sellowii Cham. \& Schlitdl. (Rosaceae) fruit nutritional potential characterization, Brazilian Journal of Biology, 2019, 79(3), 510-515.

18-G. E. Hirsch, E. M. P. Facco, D. B. Rodrigues, M. Vizzotto, T. Emanuelli, Physicochemical characterization of blackberry from the Southern Region of Brazil, Ciência Rural, 2012, 42(5), 942-947.

19-L. M. Boudechiche, M. Cherif, L.

Boudechiche, F. Sammar, Teneurs en composés primaires et secondaires des feuilles d'arbustes fourragers de la région humide d'Algérie, Revue Méd. Vét, 2014, 165(11-12), 344-352.

20-T. K. Lim, Edible Medicinal and Non-Medicinal Plants, Dordrecht, Netherlands: Springer, 2012, 555-69.

21-L. R. Howard, J. R. Clark, C. Brownmiller, Antioxidant capacity and phenolic content in blueberries as affected by genotype and growing season, Journal of the Science of Food and Agriculture, 2003, 83, 1238-1247.

22-B. M. Ruiz-Rodríguez, P. Morales, V. Fernández-Ruiz, M. C. Sánchez-Mata, M. Cámara, C. Díez-Marqués, M. Pardo-deSantayana, M. Molina, J. Tardío, Valorization of wild strawberry-tree fruits (Arbutus unedo L.) through nutritional assessment and natural production data, Food Research International, 2011, 44, 1244-1253.

23-M. Jridi, N. Souissi, M. Ben Salem, M.A. Ayadi, M. Nasri, S. Azabou, Tunisian Date (Phoenix Dactylifera L.) by-Products: Characterization and Potential Effects on Sensory, Textural and Antioxidant Properties of Dairy Desserts, Food Chemistry, 2015, 188, 8-15.

24-K. Doukani, N. Gacem, H. Benlarbi, Physicochemical and phytochemical characterization of some Algerian honey types, 
International Journal of Applied, Physical and Bio-Chemistry Research, 2014, 4(6), 1-16.

25-M. Dorais, A. P. Papadopoulos, A. Gosselin, Influence of electric conductivity management on greenhouse tomato yield and fruit quality, Agronomy, 2001, 21, 367-383.

26-T. Chao, C. Cheng, R. R. Krueger, The Date Palm (Phoenix dactylifera L.): Overview of Biology, Uses, and Cultivation, HortScience, 2007, 42 (5), 1077-1082.

27-W. N. Sawaya, J. K. Khalil, W. M. Safi,

A. Al-Shalat, Physical and chemical characterization of three Saudi date cultivars at various stages of development, Can. Ins. Food Sci. Technol. J., 1983, 16, 87-93.

28-L. G. Hêdiblè, E. S. Adjou, F. P. Tchobo, P. Agbangnan, B. Ahohuendo, M. M. Soumanou, Caractérisation physico-chimique et morphologique de trois morphotypes de pommes d'anacarde (Anacardium Occidental L.) pour leur utilisation dans la production d'alcool alimentaire et de boissons spiritueuses. Journal of Applied Biosciences, 2017, 116, 11546-11556.
29-L. G. Hêdiblè, E. S. Adjou, F. P. Tchobo, P. Agbangnan, B. Ahohuendo, M. M. Soumanou, Caractérisation physico-chimique et morphologique de trois morphotypes de pommes d'anacarde (Anacardium Occidental L.) pour leur utilisation dans la production d'alcool alimentaire et de boissons spiritueuses. Journal of Applied Biosciences, 2017, 116, 11546-11556.

30-M. Saadoudi, L. Hamebaba, M. Abdeddaim, Study of The Glucidic Fraction of Celtis Australis L. Crataegus Azarolus L., Crataegus Monogyna Jacq., Elaeagnus Angustifolia L. And Zizyphus Lotus L. Fruits, International Journal of Nutrition and Food Engineering, 2012, 6(11), 1003-1006.

31-F. Sakamura, T. Sugar, Changes in chemicals component of ripening Oleaster fruits, Phytochemistry, 1987, 26(9), 2481-2484.

32-F. A. Ayaz, A. Kadioglu, A. Dogru, Soluble sugar composition of Elaegnus angustifolia L. var. orientalis (L.) Kuntze (Russian olive) Fruit, Turk. J of Botany, 1999, 23, 349-354. 